\title{
Global recession and higher education in eastern Asia: China, Mongolia and Vietnam
}

\author{
Gerard A. Postiglione
}

Published online: 2 April 2011

(C) The Author(s) 2011. This article is published with open access at Springerlink.com

\begin{abstract}
This paper presents a perspective on the capacity of colleges and universities during past and present economic shocks. The main argument is that the environment of the global recession - an Asia far more economically integrated than during past economic shocks, with more unified aspirations to be globally competitive and socially responsibleno longer delay reforms in higher education. In fact, the global recession has become an opportune time for higher education in Asia, specifically developing countries in eastern (East and Southeast) Asia, to continue reforming governance and administration, access and equity, internal and external efficiency, and regional collaboration. Economic shocks have accelerated reforms in higher education, especially those for promoting innovation in their economies, though more is needed in improving governance and access for underserved populations. This paper examines the cases of China, Mongolia, and Vietnam as examples of how the global recession and regional integration are growing forces in shaping their higher education reform and development. The paper also identifies a series of measures for increasing the resilience of higher education systems in serving poor and vulnerable populations during economic recessions. Responses to the global economic recession by nations in eastern Asia are likely to improve the global shift in economy and human capital.
\end{abstract}

Keywords Economic recession · Higher education · Eastern Asia

\section{Overview}

During the 1980s, countries in Asia that borrowed from the World Bank and the International Monetary Fund (IMF) were instructed to cut back on government spending, including that for higher education. Likewise, during the late 1990s, many Asian colleges and universities became casualties of the financial crisis. The effects still linger in some

G. A. Postiglione $(\bowtie)$

The University of Hong Kong, Pokfulam, Hong Kong, China

e-mail: gerry@hku.hk 
countries. However, the global recession of 2008 runs counter to this trend. The response of developed nations has been less about cutting back and more about the rebuilding and strengthening of colleges and universities. At the same time, there is a growing consensus among scholars of Asian higher education that the financial architecture and governance of higher education needs reforming (Lee 2004; Mok 2006, 2008; Tilak 2004). Therefore, asking developing countries in Asia to cut back on their knowledge infrastructure is difficult to justify as developed countries do the opposite. Although there is no way to escape the difficulties of the global recession, the answer for the developing nations of Asia is not to undo the gains in higher education of the last 20 or 30 years.

Past economic shocks in Asia have also generally limited the capacity of their colleges and universities to serve vulnerable populations. These populations vary somewhat among countries, but, at one time or another, have encompassed the urban poor, newly unemployed households of the lower middle class, recently unemployed urban workers, and rural migrants in manufacturing and related sectors, as well as rural populations of women and ethnic minorities, including those with basic education. Although government responses are formulated, sometimes on the advice of donor agencies, recessions share the essential result of intensifying poverty among the poor and augmenting vulnerable populations through a massive increase in unemployment. However, the global recession differs in fundamental ways; not so much in its source or intensity, but in the rapidly changing context of regional development in eastern Asia. The environment of the global recession is that of an eastern Asia far more economically integrated than during past economic shocks, with more unified aspirations about becoming globally competitive and socially responsible as it moves toward the center of the world economic system ( ADB 2008a; UNESCO 2003). It follows that past assumptions about higher education and its function in national development need be reconsidered to enable effective responses from government and the private sector.

\section{Looking back to see ahead}

From the 1970s, international development agencies began to take a conservative view of the expansion of higher education the developing world. Contending that the rates of return were much higher for basic education, they advised countries of the risks of expanding university education. This led to a neglect of higher education and left "higher education in a perilous state" (World Bank 2002). Universities in the developed world took advantage of this period as by many top students from Asia and elsewhere looked to Europe and North American for university degrees. By the late 1990s, many developing economies in Asia began to expand higher education (Postiglione 2005; Lee and Healy 2006). However, governments preferred to focus their funds on that state supported flagship institutions (Altbach and Umakoshi 2004; Altbach and Balan 2007). In the meantime, privatization was used to satisfy the increased demand that resulted from the successful implementation of basic education and a growing middle class that could affords to spend more on their children's education. The detrimental effects of rapid privatization on educational quality are well-known and government's acknowledged the need to develop regulatory frameworks and increase monitoring and evaluation. The Asian economic crisis of the late 1990s wrong havoc on their fledgling systems of higher education, both public and private. Some financial resources were culled back and re-appropriated to basic education. However, the crisis was of paramount importance as it required more public and private universities to engage in collaboration and partnerships in order to ensure their survival and sustain their 
programs. It also led cash strapped government to permit more financial independence and institutional autonomy in higher education. By the time the world economic crisis hit in 2008, higher education systems in eastern Asia were already less dependent on government and more attuned to economic climate changes and challenges, and at least slightly more adept at creating ways to weather an economic downturn. Since this was a global recession and not an economic crisis created in Asia, the response in higher education was a growing consensus to maintain the gains of past years. Before the global recession, many Asian universities had begun to take note of how their own and neighboring universities were inching their way forward in the increasing ubiquitous global league tables. Charting the upward trajectory of Asian universities contributed to a view that increased global economic competitiveness cannot be attained by scaling back the development of higher education.

The effects of the Asian financial crisis of 1997-1998 and the response by governments tell an interesting story. In the case of Southeast Asia, the intensity of the crisis' effects varied somewhat across countries depending on their economies, share of public and private institutions, and college enrollment rates in domestic and international institutions. However, governments shared a number of response patterns.

Indonesia shifted the share of education resources toward basic and away from higher education. As Purwadi (2001:71) noted, "the crisis simply prevented pupils of low economic status from affording even the least costly university education." Applications declined at elite private colleges and universities, but some households were able to shift over to less expensive public colleges and universities, while youth from poor households were more likely to drop out. Economic subsidies from the government were reduced even while some institutions endeavored to cut or eliminate tuition fees for selected poor students. Institutions were differentially affected and some gained more financial independence and autonomy as they were forced to find alternative ways to mobilize resources.

In Malaysia, the middle class was particularly hard hit. When funds for overseas study were drastically reduced, enrollments at public institutions shot up even while the government instituted austerity measures that cut operating and development expenditures by 18\% (Hassan 2001). Low-income Bumiputra ${ }^{1}$ were hard-pressed to continue in higher education. The pressure increased as public universities were corporatized and many established foundations and subsidiaries to mobilize funds. The government responded with a National Higher Education Fund to help students afford study fees. Malaysian students overseas returned home and public-private higher education franchising developed further.

Thailand's higher education budget declined during the economic crisis. Investment expenditure was halved. Student loans were made available on a wider scale. However, the number of students applying for places declined by $30-60 \%$ and private vocational colleges could only meet a third of their targets (Varghese 2001). Dropout rates increased as children helped support their households. When enrollments began to increase again, it was in the public sector, with a $23 \%$ rise. Also, similar to Malaysia, fellowships to study overseas were canceled.

Similar effects were apparent in the Philippines, where the economic crisis initially stalled higher education enrollments, particularly in the private sector, and where quality

\footnotetext{
${ }^{1}$ Bumiputras means princes of the Earth and embraces ethnic Malays and other indigenous ethnic groups in Malaysia, where Bumiputra laws are designed to provide opportunity for the majority ethnic Malay population to balance the economic dominance of Malaysia's Chinese population.
} 
remained a key concern. Philippine households cut expenditures on nonessential goods, and education's share of the total household budget increased slightly from 10.0 to $10.3 \%$ on average between 1997 and 1998. The government provided scholarships on a limited scale. The focus was on wider social-protection strategies supported by international donors (Ablett and Slengesol 2001).

Across developing countries in Southeast Asia, college and university budgets were sacrificed in favor of school budgets. The switch from private to public institutions increased, while government subsidies or loans helped alleviate some of the hardships. More domestic study — rather than overseas study_refocused the goals of higher education. Private institutions suffered, but in some countries they formed franchises with public institutions. Public institutions became less dependent and more autonomous, and in some cases became corporatized. Twinning opportunities with overseas institutions increased. The biggest victim was quality, as investment components and governance reforms were delayed in favor of merely sustaining recurrent expenditures for minimal survival.

One worthwhile effect was that institutions gained more autonomy and responsibility for fund raising and a more entrepreneurial spirit. However, sustained reforms in governance were minimal and the quality of instruction and relevance of research remained among an assortment of areas in higher education in need of reform. As the effects of the global recession linger, there is good reason to consider how to foster innovative reforms.

Among developing countries, China capitalized on the Asian financial crisis by expanding higher education when job markets weakened but household savings and family values were substantial enough to support enrollment fees. While expansion occurred largely in the state sector, China also encouraged non-government colleges to expand, thus providing more opportunities to those from previously underserved populations. Meanwhile, it consolidated resources to attain economies of scale, introduced reforms in personnel administration, strengthened its assessment of the quality of instruction, and still managed to support the development of world-class universities.

In general, Asian colleges and universities have a checkered past in weathering recession and economic shock, especially as they impact on particular income groups, regions, and sectors of the labor market. Inadequate government responses may be due to anachronistic assumptions about the role of higher education in development. This paper argues that any further delay of substantial reforms in the governance of higher education during recession runs the risk of a long-term handicap to global competitiveness and sustained hardships for underserved vulnerable populations. Mongolia and Vietnam are two examples of nations that are facing important decisions as to how to proceed in the reform of higher education during the global recession.

Recessions, regional integration, and higher education expansion

A common viewpoint is that the Asian economic crisis was caused by a rapid withdraw of investment funding to the region and the global recession was emanated in the United States, slowed consumption there, and effected export economies in Asia (Pomfret 2010). Moreover, the shock to the export economies was cushioned by the vitality of the larger regional economy in Asia, something which reinforced the logic of regional collaboration. The Asian economic crisis is usually viewed as beginning with the floating of the Thai baht. This lead to a major devaluation and expanded the slowdown to South Korea, and across ASEAN, especially Malaysia and Indonesia. High rates of economic growth were no longer possible as GDP growth rates flat-lined or dropped, until 1999 when early 
indication of growth began to appear. The crisis highlighted the role of major players in the world economy, including a rising Chinese economy. However, the Asian economies had begun to initiate financial sector reforms in the 1990s, which unfortunately were only partially completed. This meant the Asian economies were carrying increasingly fragile financial systems, and as (Radelet et al. 1998:3) pointed out: "growing short-term foreign debt, rapidly expanding bank credit, and inadequate regulation and supervision of financial institutions." As panic set in, it was further intensified by governments and the IMF, whose disregard to the root problem imposed additional costs on Asia's recovery prospects and their higher education systems.

Since then, however, eastern Asia's movement toward regional integration became increasingly evident. With few formal free trade agreements or regional institutions until the late $1990 \mathrm{~s}$, the region forged ahead quickly with inter-state cooperation in finance and trade (Katada and Solis 2008). Regionalism in eastern Asia has become a key feature of the global political economy. This was also due to the slow process of liberalization under the WTO, and the enlargements of the EU and growing Pan-American moves to increase free trade arrangements. However, a major reason was that the Asian financial crisis of 1997-98 demonstrated the risk of contagion and investors' perception of the region as a single market. Although many Asian leaders had studies in the US, they lost much trust in the US and international institutions for protection. This propelled the search for home-grown means to protect against unpredictable global money markets (Feinberg 2000).

While Asian regionalism remains contentious in some respects, the core actors are ASEAN + 3, with China, Japan, and South Korea competing to seek initiatives within the process of regionalism, they have joined together in a number of agreements, such as a network of currency swap arrangements and there has been some discussion about an Asian Monetary Fund and common currency baskets. Thus, Asian economies are more integrated than ever before and the demand for human resources is growing rapidly.

The global financial recession affected growth in selected sectors, and higher education could still become a potential casualty (World Bank 2009a). When the region weathered an economic shock in 1997-1998, the experience provided insights for the global recession's implications for higher education and the rising social and economic demand (Lee and Rhee 1999). Sharp shifts in international finance promise to remain an occasional reality of the economic landscape for higher education as Asia drives toward the center of the global economy. Yet, such shifts need not deter reforms in Asian higher education as it expands access to more diverse populations and sustains Asia's knowledge transfer and economic growth. A recession is an opportune time for higher education to continue reforming institutional governance while it resists marginalizing populations from poorer regions and those who become vulnerable during major economic downturns (Varghese 2001).

Economic globalization has transformed the role of colleges and universities in the Asian region. Rapid expansion has been fueled by an increased demand for higher education that has been fostered by the successful popularization of basic education, rising household expectations, government subscription to the discourse of knowledge economics, human resource needs, and increased availability of distance programs, and private for-profit programs (Postiglione and Tan 2007). From institutions that prepare an elite stratum, colleges and universities are becoming institutions serving multiple stakeholders. Enrollment in higher education is expected to double in 5 years and triple in 10 years in many developing countries in this region (ADB 2008b). Among the challenges will be improving knowledge transfer to poor communities, preparation of vulnerable youth for an increasingly competitive labor market, and confidence by households to send a child to 
college or university. Institutions of higher education are also becoming symbols of national ambition during times of growth as well as recession.

During past economic crises, higher education budgets have been secondary to those for basic education. However, the global recession requires different measures, including a shift toward cost sharing among different levels of the education system, a trend that is increasing in many parts of the world (Johnston 2004; Woodhall 2007). For these and other reasons, development agencies are shifting their educational funding toward regular and higher vocational education (Sarvi 2008).

Topics worthy of examination in developing regions of Asia include the effects of the economic shift on student access and retention, changes in household perspectives and strategic decision making, innovation and resilience in institutional governance, the quality and relevance of knowledge and skills transmission, cost-sharing arrangements and the sustainability of private higher education, trends in international student mobility and transnational academic collaboration, the mobility of the academic profession, the shrinkage of the graduate employment market, and funding for research (in science, technology, and medicine) that aids poor communities (Chapman and Austin 2002; Fegan and Field 2009; Chapman et al. 2010; Huang 2006; Sakamoto and Chapman 2011). While the scope of this paper does not permit addressing these aspects in detail, it is possible to review selected literature and data regarding the experience of higher education in selected developing countries of Asia during financial slowdowns. Government policies to ameliorate negative impacts on higher education during economic crises can be reviewed and assessed for their effectiveness.

\section{Economic shocks and higher education reform: China, Mongolia, and Vietnam}

This section cites three cases of transitional economies in eastern Asia that are on the move to rapid reforms in higher education. Each introduced market forces into their economies at different times and degrees, and at a different pace. China, the largest country in the world, began a gradual reform in December 1978. It has since become the second leading economy after the United States, with the world's largest higher education system. Massive and landlocked a sparse population, Mongolia made the most radical transition to market economics, triggered by the fall of the Soviet Union in 1989. It has since seen its East European orientation matched by a tilt back toward Asia. Vietnam's economic liberalization was gradual but is rapidly become engaged in major university reforms. Developments in higher education in each country, not all necessitated by regional or global economic shocks, are reviewed below. However, there are indications that global recession and regional integration are growing forces that shape higher education reform and development in each country.

China

The global recession also took its toll in China. Even in China, where government stimulus measures have been effective in easing the effects of the recession, up to 41 million workers lost their jobs (40\% of total global layoffs), and 23 million remained out of work as of October 2009 (Cai et al. 2010). However, China is adhering to its human resource blueprint (that by 2020 young people will average 12.8 years of education), which means that enrollment in higher education will not be cut back (6 million were admitted last year), 
despite the fact that expansion has resulted in increased unemployment among colleges and universities graduates. By July 2009, 68\% of 6.11 million university graduates had found jobs, leaving nearly two million still unemployed.

Measures have been instituted to expand opportunities and find work for graduates. There is also a renewed focus on postsecondary-level vocational and technical colleges, especially as more households drop the traditional emphasis on academic higher education. This is occurring as vocational-technical and community colleges align themselves more closely with the needs of the labor market. In China's case, as well as for other countries in Asia, demography has become a key factor in higher education planning. By 2020, the number of students in primary and junior secondary education will drop by 18 million. With a rising aging population and a decline in the school-age population, a shift of resources toward basic education and away from higher education could have unfavorable long-term implications.

Between 1999 and 2004, enrollment nearly quadrupled. In 1999, enrollment in higher education stood at 1.6 million, and in 2004, enrollment was 4.473 million. According to 2007 Ministry of Education statistics, in 1990, less than 4\% of the 18-22 age group was enrolled as students in higher education compared to 22 percent in 2005. About 5 million students are admitted annually. China's higher education institutions expanded rapidly beginning in 1999 as a way to delay entrance into the labor market of large numbers of youth when the Asian economic crisis affected job opportunities. Expansion of paid university places was also a way of get households to spend at a time when the economy needed more of a stimulus. Universities resorted to banks for loans to support capital construction costs, resulting in high levels of debt. Rapid expansion also compromised the quality of higher education. Low quality in turn contributed to graduate unemployment. According to one report, only about $7 \%$ of the students about to graduate in July 2009 had managed to secure jobs by March 2009. This is down about 50\% from the same period the year before. In fact, the demand for graduates seems to have dipped by $20 \%$, due largely to the global economic slowdown (Qiwen 2009). The China's Ministry of Education reported in 2009 that the number of graduates had topped 6 million, a figure far beyond the 1.45 million who graduated in 2002 .

The global recession has not alleviated the pressure on the close to 2 million graduates who still need jobs (Zhou and Lin 2009). In January 2010, Chinese Premier Wen Jiabao warned that university graduates face a grim job market as the global slowdown takes hold of the economy (Reuters 2010). More recent reforms aimed to raise the quality of undergraduate education while broadening the curriculum to foster more creatively minded graduates who could promote the innovation needed to sustain China's economic rise. There is an increasingly popular view that graduates in China simply lack certain skills that are relevant to the needs of the labor market (Roberts 2010). For example, international companies often complain about the lack of appropriately skilled Chinese graduates. Companies have to invest in training their new college-educated staff in order to bring them up to par with the standards required for international companies. It is not only foreign companies that struggle to find skilled graduates. At a job fair in Beijing, local employers expressed concern about the quality of graduates (Patton 2009). Domestic companies often indicate a mismatch between their needs and what graduates possess. The global slowdown has put pressure on Beijing to address the shrinking number of jobs available for young graduates.

With the aim of raising quality, China has moved quickly to capitalize on Sino-foreign collaboration in higher education and propagated a law on Sino-foreign cooperation in education in 2003. While one of the major reasons for Sino-foreign partnerships has been 
to raise the quality of education in China, many believe that educational quality has remained unsatisfactory because partnerships are driven more by commercial benefits than academic motives. The lack of internal governance and quality monitoring by partners has not helped to alleviate the problem. Yet the view remains that to cut transnational partnerships in higher education would be a profound mistake, especially in anticipation of the global economic recovery (Hvistendahl 2009). For countries like China, the view is that higher education has become more important because of the global financial crisis.

Due to its size, reliance on export, low wages, predominance of state owned enterprises, and economic strategy of protecting its markets, China did not experience the Asian economic crisis in the way that many of its neighbors did. Its higher education expansion and development were not curtailed by the crisis. To the contrary, it was able to continue expanding access with the vision of a knowledge economy and logic that households would view it as an investment good that would augment the circulation of capital by the middle class who would pay the rising amount of tuition at public universities and private colleges.

At the same time, China began to attract large number of students from throughout Asia, especially from developed countries such as Korea and Japan, who could afford to pay the fees required by Chinese universities, but also students from Southeast Asia, including large numbers of overseas Chinese and others who rely on China's foreign assistance. Thus, China's higher education expansion was not affected in the same way as other countries, something that did not go unnoticed in other university systems of Asia. However, the global economic recession meant a slowdown in job creation for graduates and claims that the expansion might have been too rapid.

The effects of the global recession were also eased somewhat as the cross-border mobility of Chinese university graduates. Many began to work or take up post graduate study in Japan, Singapore, Hong Kong and elsewhere in the region. The rapid expansion in the teaching of Chinese at Confucian Institutes throughout the world also took some of the burden off employment. As the population ages and the younger generation takes on a larger labor burden to sustain the economy, China could very well find itself attracting labor and high level talent from other parts of Asia where facility in Chinese language will have increased with the number of Confucian institutes. Countries like Singapore that have slowing population growth have begun to take advantage of China's talent by establishing boarding schools for young talented students fro China who would go to university in Singapore, join the labor market after graduation, and become more easily integrated into Singaporean society. A similar situation has occurred in Hong Kong. An increasing number of students from China can be found working or studying in most Asian countries.

\section{Mongolia}

Despite the global recession, Mongolia is determined to move ahead in restructuring its higher education system (Postiglione 2010). Selected key education indicators rival those of its neighbors in northeast Asia-the China, Republic of Korea (hereafter Korea), and Japan. It has a literate population, a popularized school system, and a higher education enrollment rate that has ballooned within a few short years to nearly $80 \%$. This enrollment rate includes a thriving sector of vocational-technical higher education. Since 1990, when the country moved from a planned to a market economy, the private higher education sector has grown to encompass a third of all enrollments. Most colleges and universities are in the capital city, where $40 \%$ of the national population resides. The rest of the population, also literate and schooled, adheres to a nomadic lifestyle. English has replaced Russian as 
the official second language of this land of 2.8 million people, the largest landlocked country in the world. Historical circumstance has made Mongolia the most Europeanized state in East Asia. However, its people retained the Asian value of acquiring as much education as possible.

Despite the global recession, Mongolia ranked seventh internationally in the share of GDP (9.0\%) allocated to education, and its education law guarantees that at least $20 \%$ of the government budget is spent on education (Government of Mongolia 2006). Yet higher education receives only $12 \%$ of that amount. This made sense for a developing country in transition. However, the time is ripe for a rethink of the higher education system, including its funding structure. State universities obtain government funds for heating and lighting, but little else. One university leader pointed out that $80 \%$ of academic staff salaries come from student fees. A national fund for higher education provides coverage to one child from each civil servant's family, and support is also provided for outstanding students from poor families. However, there is also a view that higher education is a source of poverty because two-thirds of the personal loans taken by countryside cattle-rancher families is spent on the higher education of their children.

With such high literacy, school attendance, and higher education enrollment rates, as well as a sustained Asian value toward education, Mongolia would seem to be in a good position to provide equitable access to higher education and restructure the system to bring the standard of teaching and research up to internationally recognized levels. Nevertheless, the global recession has created severe limits on reform for the time being.

Mongolia faces several daunting challenges during global economic shocks. First, government spending on higher education is severely limited in comparison to other regional players. For example, the two economies of Malaysia and Hong Kong, China overshadow most Asian countries with respect to per student expenditure as a share of GDP. Mongolia's transition to a market-oriented system included introducing fees for higher education. However, unlike governments in the China, Japan, or Korea, Mongolia's can not make the same investment in its top universities. The evidence suggests that the amount of government investment in higher education does matter, not only to the quality of teaching and research but also to ensuring access to all who meet the criteria for admission. Hong Kong, spends about $30 \%$ of its education budget on higher education and has the highest concentration of top-rated universities, all government funded, in one city in Asia. Moreover, government ensures that loans are available to university students that need them. While there are also some Asian governments that allocate a smaller slice of the pie to higher education, improving access for poor populations and raising the quality are difficult to achieve with a $12 \%$ slice of the education budget for higher education.

Second, like China and Vietnam, the quality of private higher education has yet to surpass that of public institutions. Despite their short history, some private institutions are catching up and offer a few competitive programs. One view is that state institutions receive such a small amount of funding that they actually operate with state titles but in private mode. Heads of private sector institutions would like more support from the government. Some would approve of placing a third of students in state institutions with the private institutions enrolling the rest. In Indonesia, Japan, Korea, Philippines, and Taiwan, private universities enroll the majority of students-in some cases more than $80 \%$. Mongolia's private institutions enroll $34 \%$ of all students.

Third, there are also far too many institutions of higher education. With 162 institutions, the average number of students at each is about 900; a figure that do not permit attaining an economy of scale. Consolidation has been used to address this problem elsewhere. For example, the average number of students in the China's institutions was 3,112 in 1990, up 
from 1,919 in 1980 , when about $80 \%$ of higher education institutions had fewer than 4,000 students and $60 \%$ had fewer than 3,000 students. However, by 2000, 612 colleges and universities were consolidated into 250 , and several universities now have over 50,000 students. Other countries are dealing with similar problems, especially at the outset of privatization when many small colleges - sometimes with poor quality instruction-were established. After the initial phase of privatization, the need for quality assurance often ends in the closure and consolidation of many institutions.

Mongolia is a developing country that aspires, as do its neighbors in northeast Asia (China, Japan, and the South Korea), to have internationally recognized research universities. The intention to establish highly recognized research universities has to be matched by a national budget that does not skimp on funds for research and development. Some continue to argue that making a direct association between R\&D budgets and research productivity is risky. (The research and development [R\&D] budget for Hong Kong is only $0.7 \%$ of GDP, but the economy has a very high per capita rate of research output). Regardless, Mongolia's R\&D budget of $0.28 \%$ of GDP places it 70th in the world (Hong Kong ranks 50th). Colleges and universities in Mongolia spend about $1.5 \%$ of their institutional funds on research. Those in the United Kingdom spend about 7-10\%. Therefore, Mongolia's research universities will remain hard pressed without a larger national R\&D budget.

While the discovery of massive mineral deposits, Mongolia has a promising economic future. The global recession has put most higher education reform on hold. In the meantime, the economy is too weak to support its large number of university graduates and many seek employment elsewhere. The reason has a great deal to do with the quality of higher education, where major reforms are critically needed. If the above challenges facing higher education are urgently addressed, Mongolia will find itself better prepared to take advantage of the opportunities on its horizon.

Mongolia's higher education has been affected severely by both economic shocks, as well as by national politics. Highly vulnerable to international markets, it expanded higher education throughout each shock. Even as late as the global economic crisis which had a major effect on education in general, one candidate for president promised to eliminate fees for higher education. After decades of looking West, Mongolia is reestablishing its position within a far more integrated eastern Asian region. For example, its universities have established scientific partnerships with top institutions in Asia, including Yonsei University in Korea, Keio University in Japan, and Tsinghua University in China, as well as elsewhere in Asia. Mongolia's mining companies, predicted to remake the economy of Mongolia, as well as providing a major source of natural resources for the energy needs of Asia's regional economies, have become listed on the Hang Seng Index, Hong Kong's internationally influential stock exchange. The governments of the Republic of Mongolia and the Hong Kong Special Administrative Region of China have established visa-free access for citizens of both, greatly increasing opportunities for academic interchanges.

\section{Vietnam}

Since 1989, Vietnam has had one of the fastest-growing economies in the world, with access to education increasing at all levels. This includes growth in primary and junior secondary education, with a renewed focus on ethnic minority-populated areas. Vietnam's General Statistics Office indicated in 2008 that GDP had passed US \$1,000 per capita. Although low within the Association of Southeast Asian Nations (ASEAN), incomes have 
risen almost fourfold since 1989. Those living on less than US\$1 per day have fallen from $60 \%$ to below $12 \%$ (World Bank 2008). Vietnam experienced two decades of rapid economic growth at an average of 7.4\% a year between 1989 and 2008. However, export growth slowed as the global recession took hold and inward investment declined (Picus 2009).

Rural populations, particularly women and minorities, were the first victims of the economic downturn with a rise in jobless rates. Over $20 \%$ of migrant workers have returned to their home provinces since the beginning of 2009, having lost their jobs in industrialized areas. The country implemented an economic stimulus package of more than US $\$ 8$ billion to address the crisis. With many migrant workers and extensive remote regions populated by ethnic minority groups, more support for basic education and pipeline programs that widen the pathways to higher education for these groups continue to be needed.

The recession is an opportunity for Vietnam to focus more intensively on the socioeconomic development of its poor and vulnerable populations. The rapid period of economic development that preceded the global recession saw increased educational opportunities across diverse populations. The recession threatens a setback in socioeconomic development and in access to higher education at a time when Vietnam has been working to improve the quality of its higher education system (Harman et al. 2010).

Vietnam aims to continue in its aim to reach the Millennium Development Goal of Education for All by 2015. However, it also plans to move ahead with its bold plans for higher education. This includes a major upgrading of the quality of its universities, which it sees as central to its economic rise and regional integration. As Huong and Fry (2004): 301 note: "The country's success in realizing its intellectual potential will depend on improving both the quality and efficiency of its university system." Vietnam has rapidly expanded an indigenous system of higher education that aims to strengthen a knowledge economy with graduates that can adapt to new technologies and flexible labor markets (Lee and Healy 2006). The continued reform and development of universities in Vietnam is essential for it to become "a major player on the world scene economically, culturally, and intellectually" (Huong and Fry 2004: 329).

The highest proportion of university graduates, over 70 percent, are employed in technical and professional occupations (Sakellariou 2010). In transition economies like Vietnam, occupation premiums increase over time along with the emphasis on skills of the new expanding labor markets. It is still possible for the labor market to absorb university graduates even though making university education more relevant to the workplace remains a work in progress. Yet, like elsewhere in Southeast Asia's rapidly expanding higher education sector, quality is a problem, especially in terms of how a university education aligns with the needs of the labor market. For example, a World Bank blog from an age 21 unemployed new graduate with a bachelor degree recounts what is increasingly common:'I expected to find a job easily since I have a degree in computers. But, after going to multiple interviews, I found out that firms are hesitant to hire me because despite my degree, they have to train me to meet their work requirements. It is easier for these firms to hire a graduate with a couple of years of experience instead" (Jimenez 2010).

Vietnam plans to open a new science university in 2010. The Hanoi University of Science and Technology (HUST) aims to have a 10\% intake of foreign students, a good number from the Asian region. The recruitment of academic staff will include half of whom can be considered as having attained an international standard of excellence, as indicated by the publication of research papers in top international journals. HUST would be part of a national plan to establish four world-class research universities by 2020 . The 
other three universities include the Vietnam-Germany University, opened in 2008 in Ho Chi Minh City, and two other institutions, including the planned American International University (Down 2009, World Bank 2009b).

The Higher Education Development Policy Program, along with the Second Higher Education Project and the New-Model Universities Project, supports the Government's Socio-Economic Development Plan 2006-2010 and its Higher Education Reform Agenda. These programs aim to strengthen governance, rationalize financing, improve the quality of teaching and research, improve accountability for performance, and enhance transparency in financial management within the higher education sector (World Bank 2009c).

Vietnam also has a thriving sector of vocational-technical education. This growth in postsecondary education not only includes universities. Vietnam has established a network of community colleges that provide a vocational and technical education within a flexible structure of instructional service. Such institutions tend to be more resilient during a recession. Reforms in higher education that involve the establishment of a system of community colleges helped expand opportunities to bring educational progress and jobs to poor communities. As Dang and Nguyen (2009: 97) point out with respect to community colleges: "This ensures a social balance in education-training that helps the poor, especially talented poor students in socio-economically-backward localities, who find opportunities to access higher education." An important measure of socioeconomic success for Vietnam's higher education system will be the ability of its community college system to encompass poor rural populations, including women and minorities, and urban poor who become increasingly vulnerable during recessions due to the rise in jobless rates.

Vietnam is an example of a country determined to develop higher education throughout the global economic crisis, even though it still has a way to go for basic education development. It sees itself in a strong position to develop rapidly in higher education and has moved toward a gradual acceptance of private higher education and public-private partnerships. It has also taken an increasing role in the regional integration and hosted the China-ASEAN Forum on Social Development and Poverty Reduction in 2009. In higher education, Vietnam has participated in the harmonization activities underway across eastern Asia. Among the multiple organizations promoting cross-border harmonization efforts are the ASEAN University Network (AUN), the Asia Pacific Quality Network (APQN) and South East Asia Ministers of Education Organization's Regional Center for Higher Education and Development (SEAMEO-REHID). The themes that cut across these efforts generally include promoting collaboration around issues of teaching, research, student and staff mobility, and quality assurance (Chapman et al. 2010). Within Asia, its partnerships in higher education have continued to grow, including the Okayama-Hue International Master's program in Sustainability of Rural and Environmental Systems between Hue University and Okayama University. This venture is one of the pioneering joint-training programs in the field of environment and agriculture both in Japan and in Vietnam. The students pay a fee to study for 1 year at Hue University and if they pass endof-course examinations, they will be funded for their 1 year at Okayama University and conferred an MS degree by both Okayama and Hue University.

\section{A national perspective on higher education during recessions}

A higher education system is a national endeavor that strengthens capacity to participate effectively in an increasingly competitive global knowledge economy. It is also an enterprise that works best when it marshals talent and fosters leadership and commitment 
from all sectors of the national population (Task Force 2000). A financial crisis slices into the heart of this national endeavor by heightening the conditions that marginalize selected populations (ILO 1998). The poor remain affected, while the ranks of the vulnerable population grow larger as more citizens suddenly find themselves bereft of the financial wherewithal to cope. Moreover, economic crises and recessions have generally damaged the competitive edge of higher education in Asia. Rather than viewing such times as opportunities to proactively push ahead with major reforms that over the long term will sustain the dynamic rise of Asian higher education within the global system, there is less emphasis on long-term planning than on short-term measures to attain financial buffering and minor management reorganization.

Despite the recent trend toward massification in higher education, students from poor and vulnerable populations in the developing countries of the Asian region are less prone to enter and complete a tertiary education during a recession, and their absence diminishes the representation of national diversity in colleges and universities (Altbach and Umakoshi 2004). Moreover, when poor populations do manage to attend and graduate, they are less likely to locate employment in a depressed labor market. Other populations become more vulnerable and cannot afford private higher education. They are limited in seeking higher education overseas and governments are more likely to reduce scholarships for overseas study.

For poor and vulnerable populations, household finance affects decisions about whether to attend regular or vocational colleges, or to defer a higher education. Economic hardships experienced by households during a recession can affect the ability of students to complete their studies. It becomes more difficult for some households to pay education fees and their children may not be able to repay loans, especially when they are unable to locate employment after graduation. Some households may decide to defer higher education opportunities or select more practical alternatives to an academic track. While household savings and the value that families place on education help sustain access rates in some countries, the choice of what postsecondary institution to attend and what major subject to study becomes of increasing concern to students and their families.

Students from poor and vulnerable populations often attend institutions more likely to experience a drop in the quality of instruction during a recession, thus further decreasing student competitiveness after graduation in an already tightly stretched labor market.

Finally, cutbacks in higher education due to recession also have the potential to affect the amount of funding available for research in the fields of medicine, science, and technology that help poor communities overcome health threats, increase food production, and improve conditions associated with development.

To be sure, the development issues and challenges will differ across the countries of the region. Whatever the case, ministries of education and college and university administrators will be confronted with more complex situations that require increasing strategic governance capabilities (Postiglione 2006). While there were generally major declines in university budgets during the Asian economic crisis of the late 1990s, some places soon began to expand enrollments. Enrollments rose in many of China's universities. Public universities diversified and increased their offerings of market-driven courses. However, this expansion took its toll on the quality of instruction. In countries with large private sectors of higher education, like Indonesia and the Philippines, many households with children in private higher education or in overseas colleges and universities moved them to public universities in the home country, where the fees were less and subsidies were more readily available. This substitution effect from private to public higher education affected the management of academic staffing, but it also initiated higher levels of management 
autonomy and stricter measures of financial accountability. Public and private colleges and universities tried to twin with overseas institutions to lower costs, and some tried to team up with banks to foster offers of long-term, low-interest loans to students.

The one constant challenge to higher education in any recession is bound to be the rising unemployment rate among graduates. Unfortunately, this was already an emerging issue as a result of the sudden regional massification of higher education that grew at the turn of the century. Still, patterns differ across countries. For example, unemployment of tertiary education graduates in some countries has been far worse than in others. Moreover, the patterns of unemployment may differ among graduates of public or private institutions, as they do among graduates of regular or vocational-professional institutions of higher education (Postiglione 2009a, b, c, d).

Income groups disproportionately affected

Unlike the global recession, the Asian crisis of 1997-1998 resulted from overambitious private sector investment. The declining value of currencies led to crises in banking and manufacturing that eventually resulted in a loss of jobs and a decline in household income. The root cause was not public sector inefficiency but rather the unrestricted inflow of private capital and its sudden withdrawal. Private domestic investment and human capital still drive growth in most places in Asia. Since private colleges and universities in Asia also outnumber public ones in most countries, public confidence can more easily be shaken during a recession if higher education access and quality experience a setback.

Aside from the poor, the rising middle class - the main clients of higher educationwere seriously affected. While there was an expectation after the economic shock of 19971998 that enrollment would be significantly affected, this was not the case in all countries. Part of the reason was that many Asian economies differed from developed economies that had large government sectors. Large public sectors would naturally be required to make severe cutbacks but the late 1990s Asian recession was a matter of private sector collapse. Therefore, employment in the public sector was not severely affected and this included public higher education. However, the emergent middle class was hard hit with job losses. Still, its demand for higher education did not change. Government institutions of higher education continued to operate and represented hope for the future to a class that associated its rising status with the dual pillars of wealth and education.

Since the publics' sectors were small and not deeply affected, higher education was not devastated on the same scale as the private sector. Private higher education revealed its fragility and lack of stamina within a financial meltdown. Although the massification of higher education had not started at the time of the 1997-1998 crisis, a large proportion of the colleges and universities in Indonesia and the Philippines were private institutions. China, Malaysia, and Mongolia had also begun to establish private colleges and universities but they represented a small proportion of the total. Vietnam led the way in the privatization of higher education in country and among its neighboring economies of Cambodia and the Lao People's Democratic Republic. The two major urban centers of East and Southeast Asia with market economies-Singapore and Hong Kong, China-had not strayed from a public sector-dominated system, though they have begun to do so since then. In most cases, the 1997-1998 crisis caused a decline in employment and household income that led to a steady divestment of income elasticity, which affected enrollments in private higher education. 
Those households with substantial savings were willing to expend part of it for educational purposes. Where household savings are substantial, this Asian pattern exhibits itself in many cases. China expanded its higher education at the end of the twentieth century, which would have been impossible without the amount of household savings that families were readily willing to make available for study costs. There are similarities in the global recession in other Asian countries. Even when household savings are low, Asian families are willing to borrow and take out loans for their children's education (as noted for Mongolian cattle-rancher households, above).

In short, the 1997-1998 crisis did not shake the strong commitment to higher education of poor and vulnerable populations. However, attendance was weakened in selected institutional sectors by financial hardships. When household savings were low, decisions about education costs were made on more pragmatic grounds. The quality and relevance of education during economic setbacks becomes increasingly important. Since recession of the late 1990s, quality assurance measures in Asian higher education have been increasingly promoted by the ASEAN University Network, an organization under the auspices of the Association of Southeast Asian Nations (ASEAN) (UNESCO 2004). The Internet has also become important for households as a source of information for making decisions about higher education in some countries, but in others there is still a need to improve the availability of both the information for decision making, and reliable and inexpensive counseling services for prospective students.

\section{Perspectives on responding to economic crises}

A time of recession also offers opportunities to take higher education reform forward in Asia's developing countries. Rather than conceive of responses to the recession as life boats to bring the system back to safety, responses can best be viewed as a way of exploring growth strategies to stimulate college and university reform beyond restoring past levels of access to poor and potentially vulnerable populations. Therefore, there is good reason at this critical juncture to gain a deeper understanding of trends during past and present slowdowns of public expenditure for higher education, effects of slowdowns on labor markets, and their implications for poor and vulnerable populations. While the origins, characteristics, and paths to recovery of the 1997-1998 crisis differ in fundamental ways from the global slowdown, many of the deleterious effects are the same.

As the recession recedes, the challenges of access to and relevance of higher education in developing countries in this region will not disappear. Even developed countries at the height of their economic prowess must constantly be vigilant about how to ensure that opportunities for a higher education are not reserved for privileged groups in society. However, developed countries have been far more successful in putting the mechanisms in place, including improved governance, that effectively deal with problems of access and relevance.

Therefore, the manner in which the global economic situation is addressed in Asia has long-term implications for the reform of higher education. In short, colleges and universities are essential for national development and in times of economic crisis, and it is mistaken to consider them as parts of the education system that can be sacrificed. They not only offer hope and confidence to poor and vulnerable populations, but also make contributions that are invaluable to national development. It is in times of recession that the opportunity arises to fine-tune institutional governance and policies. 
Some common responses in higher education during the 1997-1998 crisis were budget cuts, staff reduction, less hiring, wage freezes, delays in building, tightly regulated utilities and maintenance, postponed library purchases, and canceled travel grants for international conferences. Declining household incomes were met with policy responses that increased the availability of subsidies for higher education. During that crisis, cuts in higher education were more on investment budgets than recurrent budgets. In response to students dropping out, student support systems were provided, including grants, loans, and scholarships. In some cases, they worked. However, results varied across countries and income groups. Private colleges and universities were strongly affected by drops in enrollment and diminished stock portfolios exacerbated the problem and required austerity measures that affected quality. Some families made a switch from fee-paying private higher education to less expensive public institutions.

Countries such as China and Malaysia had large numbers of students studying overseas. Countries that had as much as a fifth of students studying overseas inevitably had to reduce fellowships and scholarships to study overseas. Although some countries tried to maintain overseas study fellowships, a more useful response was to establish a credit transfer arrangement that provided an opportunity for students to return from expensive overseas study and continue their education at home institutions.

Such responses to the global recession provided colleges and universities with more autonomy from government, financially or otherwise. This was an encouragement to the private sector and some new universities resulted. Since Western countries were less affected by the Asian crisis but increasingly affected by competition for students and the pressure to internationalize, representatives from many of them came to Asia to recruit students and fostered an increase in twinning programs.

Wealthy countries of the region could provide innovative financial support to students of higher education, despite the economic crunch, because of their access to resources, both institutional and technological. Students could be provided with graduate retraining at public expense. Colleges and universities offered courses in information technology, life sciences, and generic skills to make their graduates more marketable. Poorer countries had to cut back on their educational budgets and resorted staff retrenchment. This led to creative policy approaches like enhancing university autonomy and strengthening the capacity of these institutions to cope with sudden resource cuts.

The 1997-1998 crisis demonstrated that existing safety net systems were inadequate. Government responses were limited and only minor reform in higher education resulted from the experience. That is not to say that the experience was not useful. More than anything else, it appears that the global recession provides more of an opportunity to consider reforms in several areas, including policy and regulatory frameworks, governance and management of higher education institutions, and equitable access and support for disadvantaged students. At the same time, better regional cross-border collaboration among developing and developed economies in the eastern Asian region holds promise for new forms of resource and cost-sharing arrangements. This also extends beyond the region to transnational collaboration and cost-sharing with colleges and universities in other parts of the world. Finally, aspirations within Asia for the region to become more globally competitive, not only as a knowledge economy but also as an area with more world-class universities, mean that research and innovation in science and technology need to be sustained during a recession.

The 1997-1998 crisis also confirmed the usefulness of periodic policy forums and other occasions where policymakers, scholars, and academics can come together to design systematic strategies for the development and improvement of higher education. Regional 
perspectives and consultations are needed. For example, Singapore avoided the 1997-1998 crisis by having invested in higher education; so did China to some extent (Postiglione 2005).

\section{Lessons of the global recession}

Students from poor and vulnerable populations are not only less likely to find ways to cover their course fees, but are more likely to make decisions about their education based on limited knowledge of the quality of courses of study and their relevance to rapidly shifting labor markets. During this recession, a downward spiral in labor markets makes students and their families less convinced about the return rate for their investments in higher learning. This is also why their willingness to further their education beyond secondary school becomes more tenuous during recessions. The quality of vocational higher education and community colleges that have closer ties to the labor market will be a more important consideration. Those that do enter postsecondary institutions are more likely to drop out than other students. Whatever the case, the recession must not result in a situation that provides an unfair advantage for better-off groups that have escaped the worst excesses of an economic crisis.

Another response from the 1997-1998 crisis was the caution and concern about underfunding basic and senior secondary education. For example, sudden and large shifts of government financing to higher education in countries with developing market economies can be perceived as placing adequate financing for basic and secondary education at risk. Some evidence shows that on average, low-income countries spend as much as 14 times more on higher education as on a secondary school student and 34 times more than on a primary school student (ADB 2008b; Glewwe and Kremer 2006). This disparity is a risk at the best of times, and an even greater risk during a recession. Therefore, a recession calls for urgent action, in particular the kind of cost-sharing and partnerships that will reduce the risk of widening disparities and ensure sustainable financing for all sectors.

The tendency for governments to protect basic and secondary education budgets during a recession, while understandable, can be short sighted. It is inevitable that higher education per student costs will remain well above other levels within the system. Yet countenancing inequity in higher education during a recession can have disastrous implications over the long term. Aside from the obvious loss of talent and the marginalizing of the poor, there is also a loss in the knowledge and skills available to serve in the social and economic development of poor communities.

During recessions, the sense of corporate responsibility becomes less robust and compromised by financial constraints (Salmi and Bassett 2009). Foundations and alumni may cut back on contributions aimed at for helping poor students. Other private funding sources for university research that focuses on the plight of poor and vulnerable communities may be affected. The private sector and civil society need to respond by maintaining loans, scholarships, and deferred payback periods. Moreover, private institutions need to respond by providing students from poor and vulnerable populations with better information about course choices and labor markets. International groups that establish higher education programs in Asia need to avoid exploiting poor and vulnerable students for economic gain. Also, international foundations that support scholarships for students from poor regions need to ensure that these students are supported to study in programs that will aid community development in the regions from which the students come. 


\section{Selected recommendations}

Tuition assistance, subsidies for poor and vulnerable students, and loans

One of the useful lessons of the 1997-1998 crisis was the key role played by emergency subsidies to poor students. Though limited, these measures were essential for sustaining access to education and education completion rates. Nevertheless, the amounts and the means of selection and distribution of subsidies require greater transparency. No capable student should be prevented from continuing his or her education due to poverty.

Part of the answer would seem to be a national system of loans, rather than free education. The experience of developing countries with respect to student loan schemes is varied. Those developing countries which do not have the infrastructure needed to institute a comprehensive loan scheme are cautioned about abruptly starting one. Small countries such as the Lao People's Democratic Republic and Mongolia have different management challenges for implementation of a comprehensive system of student loans than large countries such as China or Vietnam. Measures need to be developed to ensure that loans do not become misdirected by recipients, whose families may be facing strong transitory financial crisis.

One way to address such challenges is to involve the institutions directly, though this may add to costs of maintaining records on the part of the institutions. In this respect, a proper balanced scheme should be reached. The aim in all cases should be to eventually launch a viable system of nationwide student loans for higher education, one that can survive amid future economic shocks and also guarantee a high degree of cost recovery.

Can current conditions support a more sophisticated system of recession proof student loans? The experience of developing countries with student loans was encapsulated in a World Bank paper (2009b). It is useful to examine the best practices in the different student loan systems of developing countries. Sarvi (2008) has taken note of studies by Ziderman (2004)and Woodhall (2007) that assessed the implementation of student loan schemes in five Asian countries. The study revealed weaknesses in areas such as "financial appraisal, forward planning, monitoring and evaluation, inadequate targeting, and inefficiency in collection" (Sarvi 2008:10).

Information and guidance for students from poor and vulnerable populations

Students, especially those from the first generation in their family to attend college or university, need guidance and protection from substandard higher education. This is especially needed during recessions when recourse cutbacks may decrease the quality of instruction in higher education. It is already clear in the global recession that many households are concerned about the quality of higher education. However, the decision on which institution to attend should still be a personal decision. Students who are willing to pay full fees and not get tuition support should be able to attend the academic programs they choose. Especially for students who receive tuition assistance, there is a need for government protection and a guarantee that they are receiving a quality education that has a good possibility of leading to productive employment.

Labor markets and community-based vocational and technical higher education

As higher education has rapidly expanded in many Asian countries, the number of students unable to locate appropriate employment opportunities after graduation has greatly 
increased in some countries. The recession has intensified this problem. While massification of higher education provides more opportunities to poor and vulnerable populations, it also comes with higher fees for tuition, accommodations, books and other supplies. While the status of regular higher education has remained consistent and rooted in traditional values, there are increasing signs that households are expecting greater relevance of higher learning for the labor market.

Several developing countries in the region are responding to the pressure for greater relevance by placing more emphasis on higher vocational and technical education. However, there is a need to intensify the support for community-based vocational and technical education that can react quickly to rapid changes in the job markets and shorten the time to complete diplomas and degrees. These institutions also need to focus on generic skills, including communication, problem solving, and creative thinking that will help graduates adjust to future economic shifts that could cause restructuring of labor markets. These institutions also need to stay socially relevant to match local community development trends. As community college models have become disseminated across an increasing number of countries, they have demonstrated a high degree of flexibility in the delivery of instructional services, especially for underserved populations, and have helped students address the rapidly changing economic landscape.

\section{Performance-based measures}

Quality indicators related to performance can decline during a recession. The emphasis given to performance indicators across higher education systems in the eastern Asian region differs significantly. A recent study revealed that academic staff in developing countries like China and Malaysia saw less of a performance orientation in their institutions compared to academic staff in more developed economies like Hong Kong, China and the Republic of Korea (Postiglione and Wang forthcoming). There is a general need to narrow the gap in the use of performance indicators and provide transparent standards for judgment about quality for prospective students and their families. With respect to instructional quality, there is a great deal that can be done to identify and reward competent teachers. The extent to which a system of career incentives can be arranged to develop and retain high quality college and university academic staff during recessions is still an area in which developing countries can make a key part of their long-term planning.

Quality teaching has invaluable downstream benefits to a society experiencing an economic downturn. Quality instructional resources need to be recognized and should match with the provision of physical and social infrastructure that support continued professional development of academic staff.

\section{Cost sharing}

There is less reason to compartmentalize the financing of tertiary education such that it becomes an automatic transfer source of funds for basic education during a recession. It makes greater sense to take a more system-wide approach toward cost sharing among different levels of the education system based on present conditions and forward planning (SEAMEO 2005).

One of the positive lessons of the 1997-1998 crisis was the provision of more autonomy for public institutions to enter into new financial arrangements for joint academic programs with private institutions. Therefore, it is worthwhile to continue to examine a range of cost-sharing 
alternatives that involve public-private financing partnerships, and to more closely scrutinize legal and social policy issues that determine the success of cost-sharing reforms.

Institutions should be able to make choices from a wide range of policy options that can be adopted to ensure partnerships. More innovative financing mechanisms should be directed at improving both greater access for poor and vulnerable populations and greater quality assurance in higher education.

Public-private partnership models, including those that involve transnational collaboration, have a role in improving the external efficiency of higher education by creating innovative ways to offer new programs at reasonable costs. In some cases, governments provide land and infrastructure, with management and teaching handled by the private sector. Through such cost-sharing, colleges and universities can recover costs and ensure sufficient salaries to attract high-quality faculty members. In other cases, governments provided autonomy to private endeavors but set the upper limit on fees charged to students and ensured minimum standards. Whatever the case, possibilities of expanding private initiatives - consistent with public objectives - can be further explored. In some countries, public support remains essential where other actors are not available and where philanthropic initiatives can supplement the government-planned expansion of higher education.

Diversification and differentiation of institutions

System and institutional diversification is on the rise, as public higher education has to respond to a more complex set of socioeconomic development challenges. Diversification is seen not only among traditional colleges and universities, undergraduate educationfocused institutions, and research universities, but also community-driven vocational and technical higher education, as well as tertiary distance education. As program needs become more differentiated, there is a need to examine a wider variety of cross-institutional articulation and funding options between public and private, domestic and crossnational, providers (Postiglione 2008).

\section{Philanthropic ventures}

Economic success in Asia has given birth to a spirit of generosity rooted in traditional values. The last decade has seen an exponential rise in the culture of philanthropy, and a significant part of this has been for the benefit of higher education. This has been the case more in some countries than others but the trend is unmistakable. There is a need to provide an environment of confidence about philanthropic partnerships by regulations that encourage involvement, provide accountability, and increase transparency, in order to help identify niches where fresh philanthropic partnership approaches can be launched to address needs in teaching, research, and service functions of colleges and universities.

\section{Upgrading of research}

Much of tomorrow's socioeconomic development will be inextricably tied to higher education, including funding for university research laboratories (Postiglione 2009e). This funding can be used to support research in science, technology, and medicine that aids poor communities, as well as research focused on the effects of climate change on the Asian environment (ecological, economic, social, etc.). The number and quality of research universities will increase. However, there is a need to consider strategic possibilities in an 
Asia-wide context. Research universities are the most expensive component of higher education, and their outputs are not always measurable in the short term. However, wellestablished research universities will become an indispensible part of regional integration into the global economy with important long-term contributions for facilitating innovation.

Regional strategies to attract international students

For many years, Asia has contributed the largest number of foreign students to colleges and universities in the United States, United Kingdom, continental Europe, Canada, and Australia (Raychaudhuri and De 2007). In anticipation of future recessions, countries in Asia can be more proactive in attracting international students from outside the region. Along with increased trade and economic cooperation, Asian countries can foster a flourishing trade in educational services. Intraregional mobility of students is increasing and forecast to expand further with rising levels of science and technology. One study of intraregional mobility revealed that "as East Asian markets have been experiencing increasing enrolments from other East Asian countries throughout this decade, some traditional destinations have experienced noticeable declines in enrolments from some major East Asian markets or a flattening of demand" (JWT Education 2008: 11). Universities in eastern Asia are now very active in recruiting international students (Table 1). Intraregional student mobility in eastern Asia over the medium to long term will continue to increase as the rate of student flows to Western countries slows. Tuition fees are between a quarter and a fifth of those in developed countries. Regional cooperation in this respect has advantages and collectively, Asian countries may be able to mitigate some of the impact of global recessions on their populations.

\section{Conclusion}

The global economic crisis has accelerated the need for Asian universities to engage internationally, and to create regional mechanisms through which students and faculty members can move more easily from one country to another. The reform of higher education is central to continued internationalization for economic and social development. Although the global recession has hit some Asian countries harder than others, the

Table 1 Outlook of international higher education students

\begin{tabular}{|c|c|c|c|c|c|c|}
\hline \multirow[t]{2}{*}{ Country } & \multicolumn{5}{|c|}{ No. of students } & \multirow[t]{2}{*}{ Growth rate $(\%)$} \\
\hline & 2000 & $2005^{\mathrm{a}}$ & $2010^{\mathrm{b}}$ & $2020^{\mathrm{b}}$ & $2025^{\mathrm{b}}$ & \\
\hline China, People's Rep. of & 218,437 & 437,109 & 760,103 & $1,937,129$ & $2,973,287$ & 11.0 \\
\hline Korea, Rep. of & 81,370 & 96,681 & 114,269 & 155,737 & 172,671 & 3.1 \\
\hline India & 76,908 & 141,691 & 271,193 & 502,237 & 629,080 & 8.8 \\
\hline Japan & 66,097 & 65,872 & 68,544 & 71,974 & 73,665 & 0.4 \\
\hline Greece & 60,486 & 68,285 & 75,339 & 84,608 & 89,903 & 1.6 \\
\hline
\end{tabular}

Top five source countries

a Estimated

b Forecast

Source: Bohm et al. (2004) 
downturn constitutes an opportunity to move forward with measures that will sustain the region's development. Moreover, as global universities continue to shape the world of higher education, regional partnerships among universities within eastern Asia constitute a potentially pivotal development (Wildavsky 2010). In this respect, some nations have already taken the lead. Among them are Singapore, Malaysia, Vietnam, China and others, covering the spectrum of developed and developing countries. In short, almost all are increasingly engaged in cross-border partnerships in higher education (Chapman et al. 2010). There has also been a gradual tilting of these more in the direction of regional partnerships among universities, although these with developed economies in the West still pay a major role. However, such partnerships, whether East-West or regional, only moderately increased the access of poor and vulnerable populations to higher education, including during economic shocks.

Higher education in the eastern Asian region is approaching a historical moment in the sense that economic integration has reached a tipping point. The global recession provides an opportunity unlike any in the past 40 years to address the capacity of colleges and universities to serve poor and vulnerable populations. A measure of success in the next 40 years will be the extension of relevant higher-learning opportunities for all populations, especially those in the most remote ethnic communities of developing countries.

The global recession presents an opportunity to continue urgent reforms (Kuroda 2009). As the knowledge production and knowledge transfer systems of the region become as integrated as their economies, a highly collaborative layer of colleges and universities can promote high-quality, international recognition and global competitiveness. Governments and international organizations can help identify a series of centers in the region that excel in particular aspects of higher education and that have the capacity to respond to the demands from across the region. However, it is also important to anticipate future Asiawide challenges.

This paper highlights the importance of the global recession as an opportunity for new thinking about comprehensive reform in education. The longer that colleges and universities continue to underperform, the greater will be the negative impact on the economies in Asia. In fact, underperformance will only compound the effect of this and any future financial recession. The OECD has demonstrated that underperforming education systems can have disastrous consequences and significant negative impacts on national growth (ADB 2008b).

In the wake of the global recession and a return to a more stable financial environment, government responses that simply restore previous funding patterns for education will find limited improvement in outcomes. This was the case with OECD countries and there is little reason to assume this will not be the case in Asia (OECD 2009). Comprehensive policy and structural reforms in education can better ensure improved educational outcomes. Yet social protection measures remain important in the short run.

In the long term, however, broad based inclusiveness in education systems for the underserved populations, including basic, vocational-technical, and higher education, both regular and vocational-technical, is necessary to make a significantly positive impact on economic growth. This impact can be accomplished by identifying underserved, disadvantaged, and vulnerable populations, and by creating a link that allocates financial aid directly to specific cohorts, such that these cohorts maximize their learning potential, avoid the waste of talent in these populations, and build knowledge and skills capacity for a human resource base that improves social and economic development across Asian countries. 
The global economy will continue to encounter and transverse recessions, each with a unique set of characteristics. Such economic shocks reveal the fragility of colleges and universities to serve poor and vulnerable populations. While we are becoming increasingly familiar with the causes of economic crises and recessions, there has been a relative paucity of effective ideas about how to move forward, especially for colleges and universities to build up institutional resilience in time to face future global or regional recessions.

The manner in which each economic shock affects capacity is constantly evolving, with differing and numerous features. This complicates the challenge of building capacity. It is an opportune time to establish one or more regional institutes to bring together practitioners from the public, private, and academic sectors on a regular basis to analyze patterns and connect theory and practice. The aim would be to anticipate, as much as possible; to analyze the implications of potential economic downswings; and to shape new thinking about preparations, responses, and strategies to sustain the capacity of colleges and universities for serving their increasingly diverse populations equitably with relevant and high-quality higher learning.

There is a new urgency to identify and remedy deficiencies with fresh approaches and innovative policy options that embed resilience in the region's rapidly expanding system of colleges and universities. While it will not be easy to find ways to insulate higher education capacity from future economic shocks, colleges and universities must remain free to carry out their mission, encourage new partnerships, and pool ingenuity to innovate while trying to stay one step ahead in the competitive environment of knowledge production and transfer. In short, the goal is to ensure that colleges and universities can cope with future uncertain economic times and flourish within them.

Open Access This article is distributed under the terms of the Creative Commons Attribution Noncommercial License which permits any noncommercial use, distribution, and reproduction in any medium, provided the original author(s) and source are credited.

\section{References}

Ablett, J., \& Slengesol, I.-A. (2001). Education in crisis: The impact and lessons of the East Asian financial shock 1997-99. Originally presented at the United Nations Educational, Scientific and Cultural Organization (UNESCO) World Education Forum, Dakar, 26-28 April 2000. Education for All 2000 Assessment, Thematic Studies coordinated by the World Bank. Paris: UNESCO.

ADB. (2008a). Emerging Asian regionalism: A partnership of shared prosperity. Manila: ADB. http://aric.adb.org/emergingasianregionalism/.

ADB. (2008b). Education and skills. Strategies for accelerated development in Asia and the Pacific. Manila: ADB. http://www.adb.org/Documents/Studies/Education-Skills-Strategies-Development/EducationSkills-Strategies-Development.pdf.

Altbach, P. A., \& Balan, J. (Eds.). (2007). World class worldwide: Transformaing research universities in Asia and Latin America. Baltimore: Johns Hopkins University Press.

Altbach, P. A., \& Umakoshi, T. (2004). Asian universities: Historical perspectives and contemporary challenges. Baltimore, MD: Johns Hopkins University Press.

Bohm, A., et al. (2004). Forecasting international student mobility: A UK perspective. London: British Council.

Cai, F., Wang, M. Y., \& Wang, D. W. (2010). The China and population and labor yearbook (Vol. 2). Boston: Brill Academic Publishers.

Chapman, D. W., \& Austin, A. E. (Eds.). (2002). Higher education in developing countries: Changing contexts and institutional responses. Westport: Greenwood Press.

Chapman, D. W., Cummings W. K., \& Postiglione, G. A., (Eds.). (2010). Crossing borders in East Asian higher education. Springer, Berlin. 
Down, D. (2009). Vietnam: Transforming higher education. University World News, March 22. http://www.universityworldnews.com/article.php?story=20090320100538501 (Accessed on February 20, 2010).

Fegan, J., \& Field, M. H. (2009). Education across borders: Politics, policy and legislative action. Berlin: Springer.

Feinberg, R. (2000). “Asians Seek Their 'Made-in Asia' Solutions, Seoul: Korea Herald, July 5, 2000, (http://www.koreaherald.co.kr).

Glewwe, P., \& Kremer, M. (2006). Schools, teachers, and education outcomes in developing countries. In E. Hanushek \& F. Welch (Eds.), Handbook of the economics of education (Vol. 2). Amsterdam: NorthHolland.

Government of Mongolia. (2006). Master plan to develop education in Mongolia in 2006-2015. Ulaanbaatar: Government of Mongolia.

Harman, G., Hayden, M., \& Nghi, P. T., (Eds.). (2010). Reforming higher education in Vietnam: Challenges and promises. Dordrecht: Springer Press.

Hassan, A. (2001). Impact of the economic crisis on Malaysia. In N. V. Varghese (Ed.), Implications of the economic crisis on higher education in East Asia: Country experiences. Paris: International Institute for Educational Planning (IIEP)/UNESCO.

Huang, F. (2006). Transnational higher education in Asia and the Pacific. Hiroshima, Japan: Research Institute for Higher Education.

Huong, P. L., \& Fry, G. W. (2004). Universities in Vietnam: Legacies, challenges and prospects. In P. A. Altbach \& T. Umakoshi (Eds.), Asian Universities: Historical perspectives and contemporary challenges. Baltimore, MD: Johns Hopkins University Press.

Hvistendahl, M. (2009). Presidents of Asian Universities call for more international partnerships. The Chronicle of Higher Education, 55(34), 22.

International Labor Organization (ILO). (1998). The social impact of the Asian financial crisis. Technical report for discussion at the high-level tripartite meeting on social responses to the financial crisis in East and South-East Asian Countries, ILO Regional Office for Asia and the Pacific Bangkok, Bangkok, 22-24 April.

Jimenez, E. (2010). Higher education graduates in East Asia: Too few? Too many? Retrieved 16th, November, 2010, from https://blogs.worldbank.org/eastasiapacific/node/2898.

Johnston, D. B. (2004). The Economics and politics of cost sharing in higher education: Comparative perspective. Economics of Education Review, 23(4), 403-410.

JWT Education. (2008). International student mobility in East Asia. British Council, February. http://www. britishcouncil.org/eumd-information-research-east-asia-student-mobility.htm (accessed on February 20, 2010).

Katada, S. N., \& Solis, M. (2008). Permeated regionalism in East Asia: Cross-regional trade agreements in theory and Practice. In S. N. Katada \& M. Solis (Eds.), Cross regional trade agreements: Understanding permeated regionalism in East Asia (pp. 1-26). Dordrecht: Springer Science+Business Media.

Kuroda, H. (2009). Time to make Asian regionalism a reality. The Straits Times (Singapore). 12 September.

Lee, J.-W., \& Rhee C. (1999). Social impacts of the Asian crisis. http://ideas.repec.org/p/snu/ioerwp/ no2.html (accessed February 20, 2010).

Lee, M. (2004). Restructuring higher education in Malaysia. Penang: Universiti Sains Malaysia, School of Education.

Lee, M., \& Healy, S. (2006). Higher education in Southeast Asia: An overview in higher education in Southeast Asia. Bangkok: UNESCO.

Mok, K.-h. (2006). Educational reform and educational policy in East Asia. London: Taylor and Francis.

Mok, K.-h. (2008). Changing governance and public policy in East Asia. London: Routledge.

Organisation for Economic Co-operation and Development (OECD). (2009). Education at a glance. Paris: OECD. www.oecd.org/dataoecd/32/34/43541373.pdf (accessed 20 February 2010).

Patton, D. (2009). China: Pressure to improve graduate job skills. University World News. 5 July (Issue 0083). http://www.universityworldnews.com/article.php?story=20090702190256276 (accessed February 18,2010$)$.

Picus, J. (2009). Vietnam: Sustaining growth in difficult times. ASEAN Economic Bulletin. April. http://findarticles.com/p/articles/mi_hb020/is_1_26/ai_n32149050/pg_10/?tag=content;col1 (accessed February 20, 2010).

Pomfret, R. (2010). Regionalism in East Asia: Why has it flourished since 2000 and how far will it go? (World Scientific Publishers).

Postiglione, G. (2005). Higher Education in China: Perils and promises for a new century. Harvard China Review. Spring: 138-43. 
Postiglione, G. (2006). Finance and governance in Southeast Asian higher education. In B. C. Sanyal \& M. Martin (Eds.), Higher education in the world, 2006: The financing of universities. New York, NY: Palgrave.

Postiglione, G. (2008). 亚洲跨径高等教育转型 [Transformations in Transnational Higher Education].中國 高等教育學會,第29卷,第21-31頁 [Journal of Higher Education 29: 21-31].

Postiglione, G. (2009a). China's International Partnerships and Cross-Border Cooperation. Chinese Education and Society. Volume 42. Number 4, pp. 3-10. New York, NY: M.E. Sharpe Publishers.

Postiglione, G. (2009b). Community Colleges in China's Two Systems. In R. L. Raby \& E. Valeau (Eds.), Community College Models: Globalization and Higher Education Reform. Amsterdam: Springer Press.

Postiglione, G. (2009c). Institutionalizing the Community College Associate Degree in Hong Kong, with Stephen Kwok. In P. A. Elsner (Ed.), A global survey of community colleges, technical colleges, and further education in different regions of the world. Washington, DC: American Association of Community Colleges Press.

Postiglione, G. (2009d). China's community colleges: Remolding a model to meet transitional challenges, with D.Watkins and L. Wang. In P. A. Elsner (Ed.), A global survey of community colleges, technical colleges, and further education in different regions of the world. Washington, DC: American Association of Community Colleges Press.

Postiglione, G. (2009e). Establishing a research university: The case of the Hong Kong university of science and technology. Presentation at The Third International Conference on World Class Universities, Shanghai Jiaotong University, Shanghai, China, 1-5 November.

Postiglione, G. (2010). Mongolia's challenge: Becoming Asian in higher education. International Higher Education. Chestnut Hill, MA: Boston College Center for International Higher Education, No. 60: $20-21$.

Postiglione, G., \& Tan, J. (2007). Going to school in East Asia. New York, NY: Greenwood Press.

Postiglione, G., \& Wang, S. R. (Forthcoming). Governance of the academy in Hong Kong. In: Locke W., \& Cummings W. (Eds.), The changing academic profession. New Yrok: Springer Press.

Purwadi, A. (2001). Impact of the economic crisis on Indonesia. In N. V. Varghese (Ed.), Implications of the economic crisis on higher education in East Asia: Country experiences. Paris: IIEP/UNESCO.

Qiwen, L. (2009). Most college students in guangdong still await offers. China Daily. 20 March.

Radelet, S., J. D., Sachs, R. N., Cooper, B. P. B. (1998). The East Asian financial crisis: diagnosis, remedies, prospects. Brookings Papers on Economic Activity, Vol. 1998, No. 1. (1998), pp. 1-90. Stable URL: http:// links.jstor.org/sici?sici=0007-2303\%281998\%291998\%3A1\%3C1\%3ATEAFCD\%3E2.0.CO\%3B2-5).

Raychaudhuri, A., \& De, P. (2007). Assessing barriers to trade in education services in developing AsiaPacific Countries: An empirical exercise. Asia-Pacific Research and Training Network on Trade (ARTNeT) Working Paper 34. Toronto: ARTNeT, an initiative of UNESCAP and IDRC, Canada.

Reuters. (2010). http://www.reuters.com/article/idUSTRE5062AD20090107 accessed February 17, 2010.

Roberts, D. (2010). A dearth of work for china's college grads more than a quarter of the Class of 2010 has yet to find work, Bloomberg Businesweek.

Sakamoto, R., \& Chapman, D. W. (2011). Cross-border partnerships in higher education: Strategies and lessons. New York and London: Routledge Press.

Sakellariou, C. (2010). Labor market outcomes of higher education in East Asia. From http://siteresources. worldbank.org/INTEASTASIAPACIFIC/Resources/EastAsia-LaborMarketOutcomesofHE.pdf.

Salmi, J., \& Bassett, R. M. (2009). Impact of the financial crisis. Washington, DC: The World Bank. September 9.

Sarvi, J. (2008). Higher education in Asia and the Pacific region: Issues of financing and partnerships, particularly from the perspective of access, equity, quality, and diversity of higher education. Paper presented at the Asia-Pacific Subregional Preparatory Conference for the 2009 World Conference on higher education, Macau, China, 24-26 September.

Southeast Asian Ministers of Education Organization (SEAMEO). (2005). Long range planning for higher education. Bangkok: SEAMEO Regional Center for Higher Education and Development.

Task Force on Higher Education and Society. (2000). Higher education in developing countries: Perils and promise. Washington, DC: The World Bank.

Tilak, J. B. G. (2004). Absence of policy and perspective in higher education. Economics and Political Weekly, 39(21), 59-64.

UNESCO. (2003). Higher education in Asia and the Pacific 1998-2003: Regional progress on implementing the recommendations of the 1998 World Conference on higher education. Paris: UNESCO Asia and the Pacific Regional Bureau for Education.

UNESCO. (2004). Indicators of quality and facilitating academic mobility through quality assurance agencies in the Asia-Pacific Region. Bangkok: UNESCO and Thailand National Accreditation Council.

Varghese, N. V. (2001). Implications of the economic crisis on higher education in East Asia: Country experiences. Paris: IIEP/UNESCO. 
Wildavsky, B. (2010). The great brain race: How global universities are reshaping the world. Princeton: Princeton University Press.

Woodhall, M. (2007). Funding higher education: The contribution of economic thinking to debate and policy development. World Bank Working Paper Series 8. Washington, DC: World Bank.

World Bank. (2002). Constructing knowledge societies. Washington DC: World Bank.

World Bank. (2008). World development indicators. www.worldbank.org/data (accessed February 27, 2010).

World Bank. (2009a). Battling the forces of global recession. East Asia and Pacific Update. April. Washington, DC: World Bank.

World Bank (2009b). Vietnam new-model universities project. http://web.worldbank.org/external/projects/ main?Projectid=P110693\&Type=News\&theSitePK=40941\&pagePK=64308295\&menuPK=64282138\& piPK=64309265 (accessed October 13).

World Bank (2009c). Higher education development policy program project information document P104694. Washington, DC: World Bank. http://www.wds.worldbank.org/external/default/WDSContent Server/WDSP/IB/2009/03/07/000104615_20090309100532/Rendered/PDF/HEDPP0PID0Appraisal.pdf (accessed September 10, 2009).

Zhou, M., \& Lin, J. (2009). Chinese graduates' employment: the impact of the financial crisis. International Higher Education (55) Spring.

Ziderman, A. (2004). Policy options for student loan schemes: Lessons from five Asian countries. Bangkok: UNESCO and Paris: IIEP. 